Check for updates

Cite this: RSC Adv., 2019, 9, 22942

\section{Robust monolithic polymer(resorcinol- formaldehyde) reinforced alumina aerogel composites with mutually interpenetrating networks}

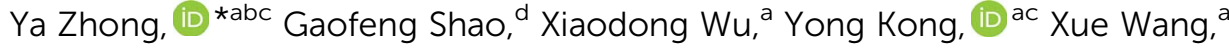 \\ Sheng Cui ${ }^{\mathrm{ac}}$ and Xiaodong Shen ${ }^{\mathrm{ac}}$
}

Monolithic polymer(resorcinol-formaldehyde) reinforced alumina ( $\left.\mathrm{RF} / \mathrm{Al}_{2} \mathrm{O}_{3}\right)$ aerogel composites were prepared using a sol-gel method and supercritical fluid $\mathrm{CO}_{2}$ drying. The formation mechanism, chemical compositions, pore structures, morphologies, thermal and mechanical performances of $\mathrm{RF} / \mathrm{Al}_{2} \mathrm{O}_{3}$ aerogel composites with different RF/Al molar ratios were investigated. The results show that the two networks of organic resorcinol-formaldehyde and inorganic alumina are completely independent of one another. The as-synthesized $\mathrm{RF} / \mathrm{Al}_{2} \mathrm{O}_{3}$ aerogels consist of spherical organic carbon particles and fibrous alumina, which possess low bulk density $\left(0.077-0.112 \mathrm{~g} \mathrm{~cm}^{-3}\right)$, low shrinkage (1.55-2.76\%), low thermal conductivity $\left(0.024-0.028 \mathrm{~W} \mathrm{~m}^{-1} \mathrm{~K}^{-1}\right)$, and high specific surface area $\left(453.26-722.75 \mathrm{~m}^{2} \mathrm{~g}^{-1}\right)$. Especially, the sample prepared with molar ratio $\mathrm{RF} / \mathrm{Al}=1$ shows the best network structure with the higher compressive strength (1.83 MPa) and Young's modulus (122.57 MPa). The resulting robust $\mathrm{RF} / \mathrm{Al}_{2} \mathrm{O}_{3}$ aerogel composites could be potentially used as thermal insulators, catalysts and adsorbents.
Received 30th April 2019

Accepted 9th July 2019

DOI: 10.1039/c9ra03227d

rsc.li/rsc-advances of pure alumina aerogels to meet the requirements of practical applications as a result of the inherent three-dimensional network, which consists of alumina nanoparticles with diameters of 5-10 nm connected by narrow inter-particle necks. ${ }^{\mathbf{1 3 , 1 4}}$ Therefore, robust mechanical and thermal resistance are the key roadblocks to using aerogel materials.

To address this issue, various structural reinforcement strategies have been attempted to improve the mechanical properties of aerogels. Incorporation of inorganic fibers, ${ }^{15-22}$ carbon fiber ${ }^{23-25}$ or advanced nanomaterials ${ }^{26-31}$ as supporting skeletons into aerogel matrixes is one of the most convenient and effective methods to overcome their fragility and poor mechanical properties. ${ }^{32,33}$ Moreover, appropriate fibers could not only strengthen the aerogel materials but also be used as opacifiers to reduce the radiative heat transport in aerogels at high temperature. ${ }^{34}$ Nevertheless, due to the relatively thicker diameter $(5-25 \mu \mathrm{m})$ and the brittleness of inlaid inorganic fibers, most of the aerogel matrix usually crack into small fragments with impairing the integrality, ${ }^{35}$ destroying the microscopic pore structures and decreasing the mechanical properties of the aerogel composites. ${ }^{36}$

Hybridization of oxide aerogels with polymers is another extensive researched approach to obtain robust aerogels by increasing their tensile strength. Depending on the chemical relationships between the polymers and the surrounding skeletal structures, polymer/sol-gel composites are divided into two categories: ${ }^{37}$ (1) the polymer and the inorganic framework are
210009, PR China. E-mail: yzhong@njtech.edu.ch

${ }^{b}$ Suqian Advanced Materials Institute of Nanjing Tech University, Suqian 223800, PR China

'Jiangsu Collaborative Innovation Center for Advanced Inorganic Function Composites, Nanjing 210009, PR China

${ }^{d}$ Chair of Advanced Ceramic Materials, Technische Universität Berlin, Berlin 10623, Germany 
completely independent of one another, namely, interpenetrating networks; (2) there is covalent bonding between the polymeric and the inorganic component, namely, crosslinking frameworks. Up to now, various polymers had been successfully integrated with oxide aerogels as reinforcement to improve their mechanical properties. For instance, Leventis et $a l^{38}$ proposed a method using poly(hexamethylene diisocyanate) as cross-linker to prepare the strong lightweight silica/Di-ISO aerogel monoliths, which are much less hygroscopic than native silica and do not collapse when in contact with liquids. Moghaddas et $a .^{39}$ developed a method of preparing the silica aerogel/rigid polyurethane foam nanocomposite by ambient pressure drying, which showed efficient thermal insulation (0.0268-0.0314 $\mathrm{W} \mathrm{m}^{-1} \mathrm{~K}^{-1}$ ) and good mechanical properties. Hu et $a l .{ }^{40}$ introduced a method of using poly(dimethylsiloxane) as reinforcement to prepare compressible and superhydrophobic polymer/graphene aerogel composites, which showed enhanced compressive strength and a stable Young's modulus. Özbakır et al. ${ }^{\mathbf{4 1}}$ synthesized the novel monolithic and crack-free PMVE-silica aerogel composites by $\mathrm{CO}_{2}$ supercritical drying and the effect of polymer fraction in solid network on drying was investigated both by experiments and simulations. Li et al. $^{42}$ fabricated silica aerogel/aramid pulp composites via ambient pressure drying by adding aramid pulps into silica sol directly, which retained the integrality and nice interface adhesion. The compressive strength was enhanced obviously up to $1.2 \mathrm{MPa}$ and the low thermal conductivity of $0.0232-0.0278 \mathrm{~W}$ $\mathrm{m}^{-1} \mathrm{~K}^{-1}$. Maleki et al. ${ }^{43}$ introduced a low-cost and time-saving method of using BTMSH and ETESB as cross-linkers to prepare lightweight polymer-reinforced silica aerogels, which showed good compression strength (11-400 kPa) and low thermal conductivity $\left(0.039-0.093 \mathrm{~W} \mathrm{~m}^{-1} \mathrm{~K}^{-1}\right)$. Therefore, the polymer-reinforced aerogel composites exhibit excellent structural integrity and mechanical performance without sacrificing other unique properties. However, the research about polymer reinforced alumina aerogel is limited.

It is generally known that interpenetrating inorganic sol-gel networks with polymers have been pursued mainly for preventing the shrinkage and cracking problems encountered upon drying of the wet inorganic gels. In this study, monolithic polymer(resorcinolformaldehyde) reinforced alumina $\left(\mathrm{RF} / \mathrm{Al}_{2} \mathrm{O}_{3}\right)$ aerogel composites were prepared using sol-gel method and supercritical fluid $\mathrm{CO}_{2}$ drying. In addition, the two networks of organic resorcinolformaldehyde and inorganic alumina were completely independent of one another. Furthermore, the details of synthesis and discussion of the effects of $\mathrm{RF} / \mathrm{Al}$ molar ratios on the microstructures evolution and physicochemical properties of $\mathrm{RF} / \mathrm{Al}_{2} \mathrm{O}_{3}$ aerogel composites are given below.

\section{Experimental}

\subsection{Chemicals}

Resorcinol (R), formaldehyde (F, 37\%w/w aqueous solution), aluminum chloride hexahydrate $(\mathrm{Al})$, deionized water $\left(\mathrm{H}_{2} \mathrm{O}\right)$, absolute ethyl alcohol (EtOH), sodium carbonate (C) and propylene oxide (PO) were used as raw materials. All of the reagents and solvents are analytical grade and used as received without further purification.

\subsection{Synthesis of $\mathrm{RF} / \mathrm{Al}_{2} \mathrm{O}_{3}$ aerogel composites}

$\mathrm{RF} / \mathrm{Al}_{2} \mathrm{O}_{3}$ hybrid sols were prepared according to the following steps. $\mathrm{RF}($ molar ratio, $\mathrm{R} / \mathrm{F}=1 / 2) \mathrm{Al}, \mathrm{H}_{2} \mathrm{O}, \mathrm{EtOH}$ were directly mixed in a pot with a molar ratio of $(0.5,0.67,1.0,1.5,2.0): 1: 48: 16$, sodium carbonate was used as catalyst (molar ratio, $\mathrm{R} / \mathrm{C}=200$ ), stirring for about $60 \mathrm{~min}$ at $50{ }^{\circ} \mathrm{C}$ for complete hydrolysis and then cooled down to room temperature. Subsequently, desired amounts of PO (molar ratio, $\mathrm{PO} / \mathrm{Al}=10$ ) was slowly dropped into the clear solution (propylene oxide was transferred by syringe through a septum, so as to reduce laboratory exposure and ensure safety). After that, the reaction mixture was further stirred for $30 \mathrm{~min}$ at room temperature, transferred to plastic molds, and the solutions were allowed to gel at room temperature within $3 \mathrm{~h}$. In order to increase the strength, the wet gels were firstly aged at room temperature for $72 \mathrm{~h}$. Afterwards, the wet gels were demolded, aged in an air oven at $65^{\circ} \mathrm{C}$ for $72 \mathrm{~h}$, and simultaneously washed with ethanol every 24 hours to exchange the water and reaction byproducts from the pores of the samples. After aging and solvent exchange, the color of monolithic wet gels tune to opaque-red from transparent-red, and the alcohol gels were dried in an autoclave (HELIX 1.1 system, Applied Separations, Inc., Allentown, PA) with supercritical fluid $\mathrm{CO}_{2}$ to form $\mathrm{RF} / \mathrm{Al}_{2} \mathrm{O}_{3}$. Finally, the as-synthesized samples were denoted as $\mathrm{S}_{1}, \mathrm{~S}_{2}, \mathrm{~S}_{3}, \mathrm{~S}_{4}$ and $\mathrm{S}_{5}$, the corresponding $\mathrm{RF} / \mathrm{Al}$ molar ratios of $(0.5,0.67,1.0,1.5,2.0): 1$.

\subsection{Measurements and characterizations}

The samples were prepared in cylinders (diameter $25 \mathrm{~mm}$, height $25 \mathrm{~mm}$ ) and the bulk density of the aerogels was determined by $\rho=m / v$ where $\rho, m$ and $v$ are bulk density, mass and volume (obtained by $v=\pi D^{2} h / 4$ where $D$ and $h$ are diameter and height of the aerogels) respectively. Thermal gravimetric analysis (TGA) and was performed by NETZSCH STA449C thermogravimetric analyzer under a constant nitrogen flow of 30 $\mathrm{ml} \mathrm{min}{ }^{-1}$ at a heating rate of $10{ }^{\circ} \mathrm{C} \mathrm{min}^{-1}$ to $1200{ }^{\circ} \mathrm{C}$. A Fouriertransform infrared (FT-IR) spectrum was recorded on a BrukerEquinox 55 spectrophotometer in $\mathrm{KBr}$ pellets with a scanning range of $4000-400 \mathrm{~cm}^{-1}$. X-ray diffraction (XRD) patterns were carried out using an ARL $X^{\prime}$ TRA diffractometer (Rigaku) with $\mathrm{Cu}-\mathrm{K} \alpha$ radiation $(30 \mathrm{kV}, 30 \mathrm{~mA})$. The microstructure was surveyed by LEO-1530VP scanning electron microscopy (SEM) and JEOL JEM-2010 electron microscope (TEM), operating at the acceleration voltage of $10 \mathrm{kV}$ and $200 \mathrm{kV}$, respectively. Pore structure properties were measured by Nitrogen adsorption/ desorption porosimetry (Micromeritics ASAP2020 surface area). The specific surface area was calculated using BrunauerEmmett-Teller (BET) and the pore-size distribution was derived from the desorption branch of isotherms by using the BarrettJoyner-Halenda (BJH) model. The thermal conductivities were tested using a Hot Disk Thermal Constants Analyzer (TPS2500S, Sweden). The compressive strengths and Young's modulus of the monoliths aerogels were measured by using an INSTRON 3382 testing machine. The test temperature was $25{ }^{\circ} \mathrm{C}$ and the test speed was $2.0 \mathrm{~mm} \mathrm{~min}^{-1}$. 


\section{Results and discussion}

\subsection{Formation mechanism of $\mathrm{RF} / \mathrm{Al}_{2} \mathrm{O}_{3}$ aerogel composites}

The reaction mechanisms of the sol-gel process are shown in eqn (1)-(3) and Fig. 1. During the preparation process, $\mathrm{AlCl}_{3} \cdot 6 \mathrm{H}_{2} \mathrm{O}$ is utilized as the $\mathrm{Al}$ precursor while $\mathrm{PO}$ (propylene oxide) is used as the initiator for the hydrolysis and condensation process, leading to the formation of the $\mathrm{Al}_{2} \mathrm{O}_{3}$ gels with three-dimensional network. Meanwhile, resorcinol reacts with formaldehyde to form hydroxymethylated resorcinol using sodium carbonate as catalyst. The hydroxymethyl groups condense with each other to form nanometer-sized RF sols clusters (classified as a phenolic resin), which then crosslink to produce $\mathrm{RF}$ gels based on the same chemistry route. ${ }^{44}$ Additionally, both $\mathrm{Al}_{2} \mathrm{O}_{3}$ gelation and $\mathrm{RF}$ gelation could occur at room temperature, the epoxide-initiated $\mathrm{Al}_{2} \mathrm{O}_{3}$ gelation in the absence of acid catalysts proceeds faster than the base-catalyzed RF gelation. Finally, the $\mathrm{CO}_{2}$ supercritical fluid drying process turns the mutually independent $\mathrm{RF} / \mathrm{Al}_{2} \mathrm{O}_{3}$ gels into $\mathrm{RF} / \mathrm{Al}_{2} \mathrm{O}_{3}$ aerogel composites, which are in the form of an interpenetrating organic/inorganic networks.

\subsection{Structural characteristics}

Fig. 2 shows the photographs of $\mathrm{RF} / \mathrm{Al}_{2} \mathrm{O}_{3}$ aerogel composite prepared with different $\mathrm{RF} / \mathrm{Al}$ molar ratios. All the $\mathrm{RF} / \mathrm{Al}_{2} \mathrm{O}_{3}$ aerogel samples are reddish brown in color, and well retain the monolithic morphology after the supercritical fluid $\mathrm{CO}_{2}$ drying process. A summary of the textural properties of aerogel samples is represented in Table 1 . According to previous reports, ${ }^{45}$ the epoxideinitiated alumina gelation proceeds faster than the base-catalyzed $\mathrm{RF}$ gelation at room temperature. With the increase of $\mathrm{RF} / \mathrm{Al}$

$$
\begin{aligned}
& \mathrm{Al}^{3+}+6 \mathrm{H}_{2} \mathrm{O} \rightarrow\left[\mathrm{Al}\left(\mathrm{H}_{2} \mathrm{O}\right)_{6}\right]^{3+} \rightarrow\left[\mathrm{Al}(\mathrm{OH})_{\mathrm{n}}\left(\mathrm{H}_{2} \mathrm{O}\right)_{6-\mathrm{n}}\right]^{(3-\mathrm{n})+}+\mathrm{n} H^{+} \\
& 2\left[\mathrm{Al}(\mathrm{OH})_{\mathrm{n}}\left(\mathrm{H}_{2} \mathrm{O}\right)_{6-\mathrm{n}}\right]^{(3-\mathrm{n})+} \underline{P O}\left[\left(\mathrm{H}_{2} \mathrm{O}\right)_{6-\mathrm{n}}(\mathrm{OH})_{\mathrm{n}-1} \mathrm{Al}-\mathrm{O}-\mathrm{Al}(\mathrm{OH})_{\mathrm{n}-1}\left(\mathrm{H}_{2} \mathrm{O}\right)_{6-\mathrm{n}}\right]^{2(3-\mathrm{n})+}+\mathrm{H}_{2} \mathrm{O}
\end{aligned}
$$
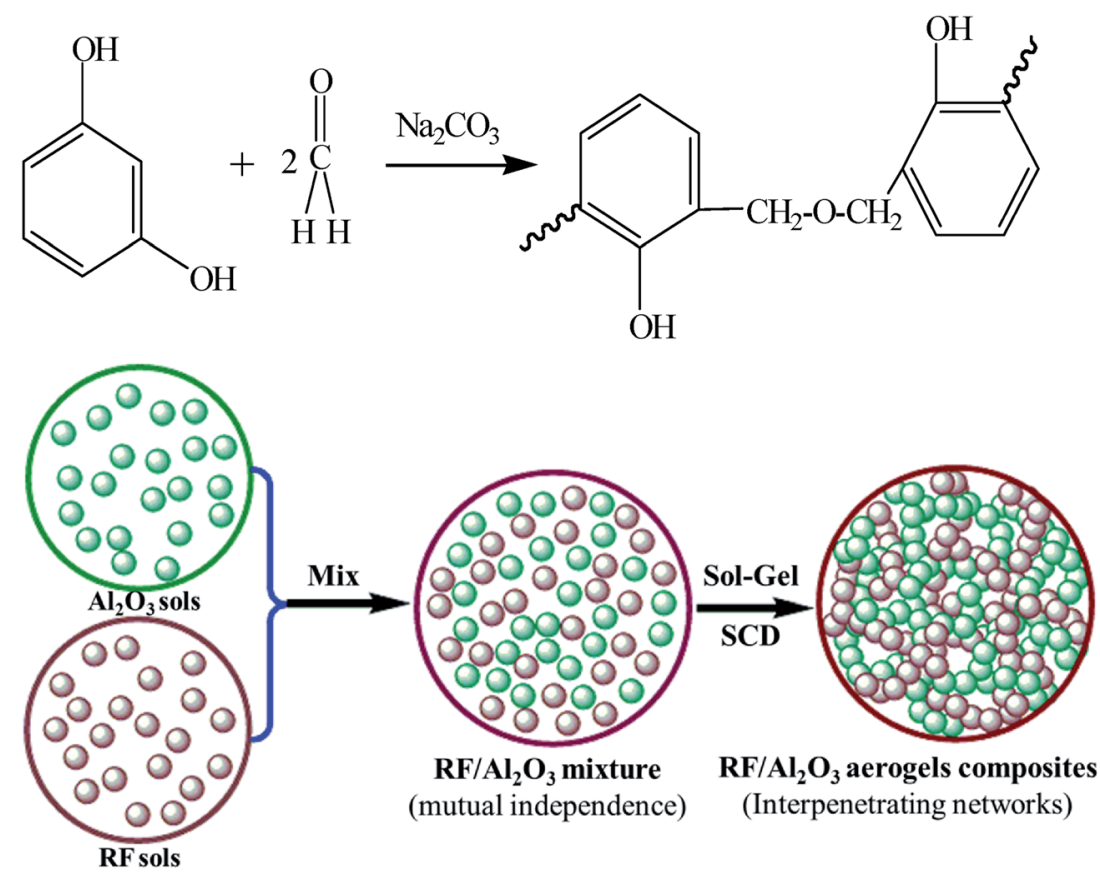

Fig. 1 Schematic diagram of the formation mechanism of $\mathrm{RF} / \mathrm{Al}_{2} \mathrm{O}_{3}$ aerogels composites.

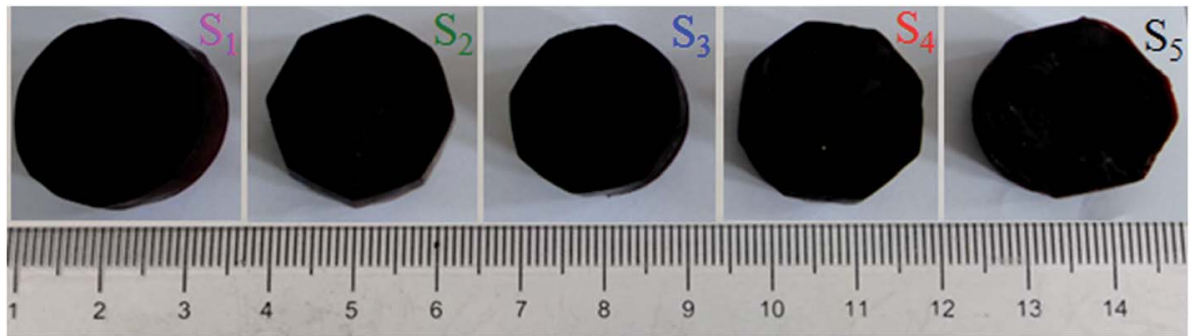

Fig. 2 Photographs of $\mathrm{RF} / \mathrm{Al}_{2} \mathrm{O}_{3}$ aerogels composites prepared with different $\mathrm{RF} / \mathrm{Al}$ molar ratios $\left(\mathrm{S}_{1}: \mathrm{RF} / \mathrm{Al}=0.5, \mathrm{~S}_{2}: \mathrm{RF} / \mathrm{Al}=0.67, \mathrm{~S}_{3}: \mathrm{RF} / \mathrm{Al}=1.0\right.$, $\mathrm{S}_{4}: \mathrm{RF} / \mathrm{Al}=1.5, \mathrm{~S}_{5}: \mathrm{RF} / \mathrm{Al}=2.0$ ). 
Table 1 Summary of the textural properties of $\mathrm{RF} / \mathrm{Al}_{2} \mathrm{O}_{3}$ aerogels composites prepared with different RF/Al molar ratios

\begin{tabular}{|c|c|c|c|c|c|c|c|c|}
\hline Sample & $\begin{array}{l}\text { Gelation } \\
\text { time (min) }\end{array}$ & $\begin{array}{l}\text { Linear } \\
\text { shrinkage (\%) }\end{array}$ & $\begin{array}{l}\text { Bulk density } \\
\left(\mathrm{g} \mathrm{cm}^{-3}\right)\end{array}$ & $\begin{array}{l}\text { Surface areas } \\
\left(\mathrm{m}^{2} \mathrm{~g}^{-1}\right)\end{array}$ & $\begin{array}{l}\text { Average pore } \\
\text { size }(\mathrm{nm})\end{array}$ & $\begin{array}{l}\text { Compressive } \\
\text { strength (MPa) }\end{array}$ & $\begin{array}{l}\text { Young's } \\
\text { modulus (MPa) }\end{array}$ & $\begin{array}{l}\text { Thermal conductivity } \\
\left(\mathrm{W}\left(\mathrm{m}^{-1} \mathrm{~K}^{-1}\right), 25^{\circ} \mathrm{C}\right)\end{array}$ \\
\hline $\mathrm{S} 1$ & 120 & 1.55 & 0.094 & 453.26 & 48.47 & 0.74 & 49.56 & 0.025 \\
\hline $\mathrm{S} 2$ & 75 & 2.14 & 0.103 & 658.43 & 39.12 & 1.29 & 86.41 & 0.027 \\
\hline $\mathrm{S}_{3}$ & 50 & 2.76 & 0.112 & 722.75 & 32.08 & 1.83 & 122.57 & 0.028 \\
\hline $\mathrm{S}_{4}$ & 135 & 1.97 & 0.096 & 643.81 & 21.57 & 1.14 & 75.08 & 0.026 \\
\hline $\mathrm{S}_{5}$ & 350 & 1.73 & 0.077 & 517.39 & 17.29 & 0.56 & 37.19 & 0.024 \\
\hline
\end{tabular}

molar ratios, the gelation time of $\mathrm{RF} / \mathrm{Al}_{2} \mathrm{O}_{3}$ mixture shows the trend of initial decrease and then increase, which results from the decrease of crystal water in $\mathrm{AlCl}_{3} \cdot 6 \mathrm{H}_{2} \mathrm{O}$ and the increase of $\mathrm{RF}$ sols. The bulk densities of $\mathrm{RF} / \mathrm{Al}_{2} \mathrm{O}_{3}$ aerogel composites are $0.077-$ $0.112 \mathrm{~g} \mathrm{~cm}^{-3}$, while the linear shrinkages are about $1.55-2.76 \%$ compared with the original wet gels. The change of bulk densities is attributed to the combined action of $\mathrm{RF} / \mathrm{Al}$ molar ratios and volume shrinkage. Additionally, all the as-prepared samples with different bulk densities process low thermal conductivities (0.024-0.028 W $\mathrm{m}^{-1} \mathrm{~K}^{-1}$ ) at $25{ }^{\circ} \mathrm{C}$, which are mainly caused by the unique nanopores and framework structures of the $\mathrm{RF} / \mathrm{Al}_{2} \mathrm{O}_{3}$ aerogel composites.

Fig. 3 shows the compressive stress versus compressive strain curves of $\mathrm{RF} / \mathrm{Al}_{2} \mathrm{O}_{3}$ aerogel composites prepared with different $\mathrm{RF} / \mathrm{Al}$ molar ratios. Table 1 lists the values of compressive strength and Young's modulus of the as-prepared $\mathrm{RF} / \mathrm{Al}_{2} \mathrm{O}_{3}$ aerogel composites. The as-synthesized $\mathrm{RF} / \mathrm{Al}_{2} \mathrm{O}_{3}$ aerogel composites exhibit an excellent mechanical property, which is one of the highest compressive Young's modulus of pure aerogels without using the structural reinforcement materials (bulk density of about $0.10 \mathrm{~g} \mathrm{~cm}^{-3}$ ) ever reported. Additionally, it is worth mentioning that the mechanical properties of $\mathrm{RF} / \mathrm{Al}_{2} \mathrm{O}_{3}$ aerogel composites with interpenetrating organic/inorganic network structures are closely related to the $\mathrm{RF} / \mathrm{Al}$ molar ratios. As shown in Fig. 3, the sample with molar ratio $\mathrm{RF} / \mathrm{Al}$ $=1$ shows the best mechanical property, and the values of compressive strength and Young's modulus are 1.83 $\mathrm{MPa}$ and

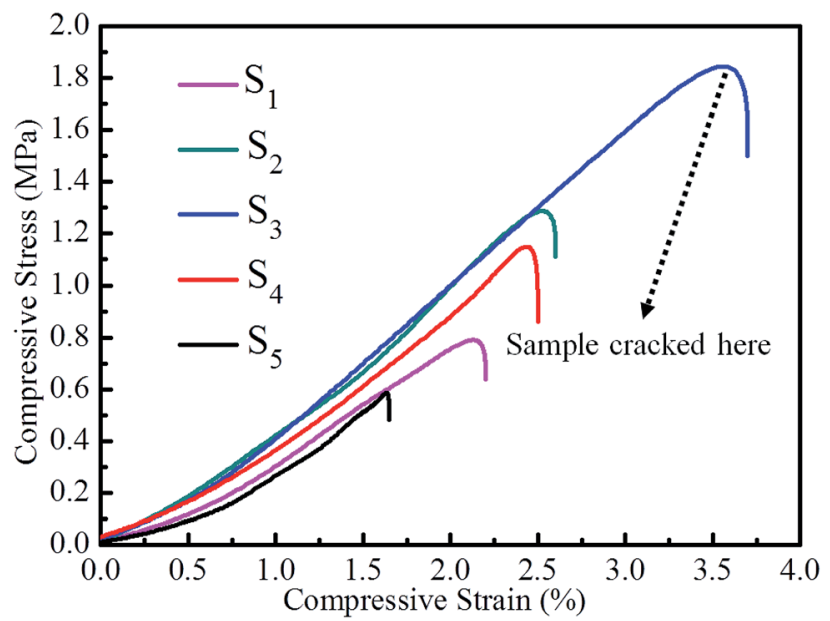

Fig. 3 Compressive stress versus compressive strain curves of RF/ $\mathrm{Al}_{2} \mathrm{O}_{3}$ aerogels composites prepared with different RF/Al molar ratios $\left(\mathrm{S}_{1}: \mathrm{RF} / \mathrm{Al}=0.5, \mathrm{~S}_{2}: \mathrm{RF} / \mathrm{Al}=0.67, \mathrm{~S}_{3}: \mathrm{RF} / \mathrm{Al}=1.0, \mathrm{~S}_{4}: \mathrm{RF} / \mathrm{Al}=1.5, \mathrm{~S}_{5}: \mathrm{RF} /\right.$ $\mathrm{Al}=2.0)$.
122.57 MPa, respectively, which is mainly caused by more uniform internal framework structure and larger bulk density. It was reported that the aerogels with equal magnitude bulk density about 0.15-0.30 $\mathrm{g} \mathrm{cm}^{-3}$, such as $\mathrm{SiO}_{2},{ }^{46} \mathrm{Al}_{2} \mathrm{O}_{3},{ }^{47} \mathrm{TiO}_{2},{ }^{48} \mathrm{C}_{2-50} / \mathrm{SiO}_{2},{ }^{49}$ layer/ $\mathrm{SiO}_{2}$ (ref. 50) aerogels, exhibited poor mechanical properties (compressive Young's modulus of 3.88 MPa, 11.4 MPa and 3.5 MPa, 23-52 MPa, 8.77 MPa, respectively), which could be due to the low densities as well as the disordered porous network morphology of aerogel materials.

Fig. 4 shows the XRD patterns of $\mathrm{RF} / \mathrm{Al}_{2} \mathrm{O}_{3}$ aerogel composites prepared with different $\mathrm{RF} / \mathrm{Al}$ molar ratios. For all the asprepared samples, they display relative broad or weak diffraction peaks, indicating the presence of amorphous organic carbon and alumina in $\mathrm{RF} / \mathrm{Al}_{2} \mathrm{O}_{3}$ aerogel composites. With the decrease of $\mathrm{RF} / \mathrm{Al}$ molar ratios, the broad diffraction peak at $22^{\circ}$ gradually disappears, meanwhile, the visible characteristic diffraction peaks of boehmite emerge out. The broad diffraction peaks with $2 \theta$ values of $15^{\circ}, 28^{\circ}, 38^{\circ}, 49^{\circ}, 65^{\circ}$ and $72^{\circ}$ correspond to crystal planes of (020), (120), (031), (200), (002), (251) of pseudo-boehmite $(\mathrm{AlO}(\mathrm{OH}), \mathrm{PDF}$ no. 83-2384), respectively. It exists as polycrystalline boehmite instead of the amorphous phase. Furthermore, the ever-present weak peaks at $37^{\circ}, 43^{\circ}$, $63^{\circ}$, and $76^{\circ}$ are due to the poor crystallization $\gamma-\mathrm{Al}_{2} \mathrm{O}_{3}$ phase in $\mathrm{RF} / \mathrm{Al}_{2} \mathrm{O}_{3}$ aerogel composites.

Fig. 5 presents the TG curves of the as-dried $\mathrm{RF} / \mathrm{Al}_{2} \mathrm{O}_{3}$ aerogel composites prepared with different $\mathrm{RF} / \mathrm{Al}$ molar ratios heat-

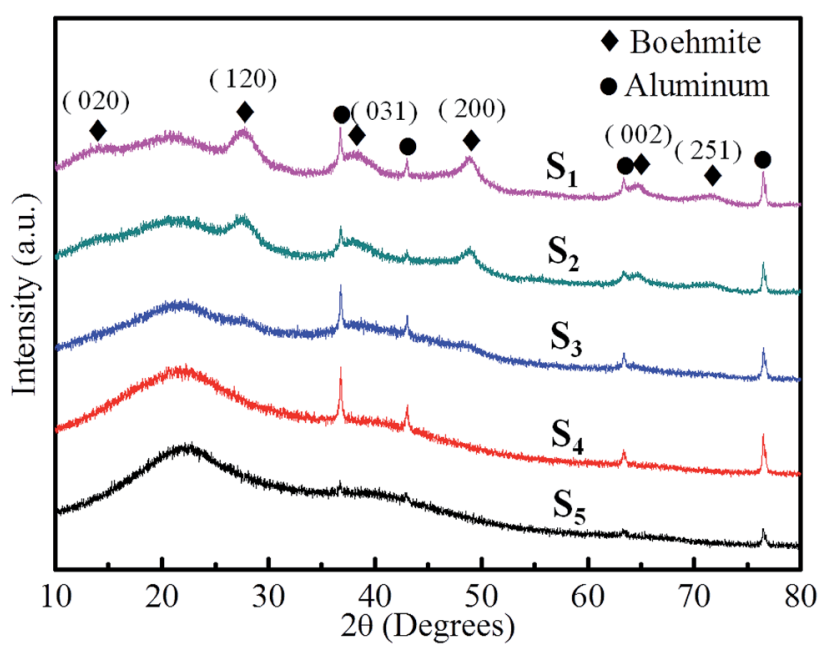

Fig. 4 XRD patterns of $\mathrm{RF} / \mathrm{Al}_{2} \mathrm{O}_{3}$ aerogels composites prepared with different $\mathrm{RF} / \mathrm{Al}$ molar ratios $\left(\mathrm{S}_{1}: \mathrm{RF} / \mathrm{Al}=0.5, \mathrm{~S}_{2}: \mathrm{RF} / \mathrm{Al}=0.67, \mathrm{~S}_{3}: \mathrm{RF} / \mathrm{Al}=\right.$ 1.0, $S_{4}: R F / A l=1.5, S_{5}: R F / A l=2.0$ ). 


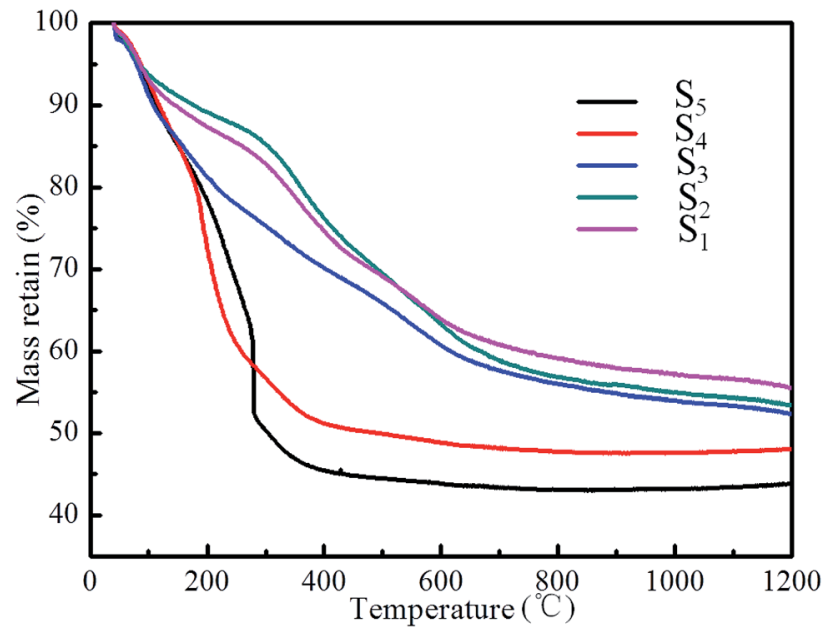

Fig. 5 TG of curves of RF/Al $\mathrm{O}_{3}$ aerogels composites prepared with different $\mathrm{RF} / \mathrm{Al}$ molar ratios $\left(\mathrm{S}_{1}: \mathrm{RF} / \mathrm{Al}=0.5, \mathrm{~S}_{2}: \mathrm{RF} / \mathrm{Al}=0.67, \mathrm{~S}_{3}: \mathrm{RF} / \mathrm{Al}=\right.$ 1.0, $\mathrm{S}_{4}: \mathrm{RF} / \mathrm{Al}=1.5, \mathrm{~S}_{5}: \mathrm{RF} / \mathrm{Al}=2.0$ ).

treated to $1200^{\circ} \mathrm{C}$ in flowing argon. The thermogram profile can be divided into three main regions. The first stage (below 100 ${ }^{\circ} \mathrm{C}$ ) is caused by the evolution of physically adsorbed $\mathrm{H}_{2} \mathrm{O}, \mathrm{CO}_{2}$ and residual solvent. In general, because of the nano-sized porous structure and high porosity, $\mathrm{H}_{2} \mathrm{O}, \mathrm{CO}_{2}$ and solvent adsorbed in the porous structure of the sample can not be removed completely during the supercritical $\mathrm{CO}_{2}$ drying process. At the second stage $\left(100-500{ }^{\circ} \mathrm{C}\right)$, an obvious weight loss of all the samples occurs due to the continuous thermal decomposition of the polymer(resorcinol-formaldehyde) in $\mathrm{RF} /$ $\mathrm{Al}_{2} \mathrm{O}_{3}$ aerogel composites. For the last stage (above $500{ }^{\circ} \mathrm{C}$ ), all the TG curves of the $\mathrm{RF} / \mathrm{Al}_{2} \mathrm{O}_{3}$ aerogel composites tend to smooth and stabilization. The mass remaining of the samples $\left(\mathrm{S}_{1}-\mathrm{S}_{5}\right)$ at $1200{ }^{\circ} \mathrm{C}$ are $56 \%, 54 \%, 53 \%, 50 \%$ and $45 \%$ of the original, respectively. According to previous reports, ${ }^{51}$ the TG curves of the samples $\left(\mathrm{S}_{4}, \mathrm{~S}_{5}\right)$ with molar ratios $(\mathrm{RF} / \mathrm{Al}=1.5,2.0)$ similar to the pure RF aerogel under the same conditions, which gives the initial mass loss of adsorbed solvents below $100{ }^{\circ} \mathrm{C}$ and only one additional step above $400{ }^{\circ} \mathrm{C}$, yielding at $700{ }^{\circ} \mathrm{C}$ a carbon aerogel with a mass loss of $\sim 50 \%$ of the original. In addition, unlike the other mutually interpenetrating resorcinolformaldehyde/metal oxide $\left(\mathrm{RF} / \mathrm{MO}_{X}, \mathrm{M}\right.$ : $\left.\mathrm{Fe}, \mathrm{Cu}\right)$ networks, ${ }^{52}$ the TG curves of as-synthesized $\mathrm{RF} / \mathrm{Al}_{2} \mathrm{O}_{3}$ aerogel composites suggest that there is no reaction takes place between $\mathrm{RF}$ and $\mathrm{Al}_{2} \mathrm{O}_{3}$.

Fig. 6 presents the FT-IR spectrum of polymer $(\mathrm{RF}), \mathrm{Al}_{2} \mathrm{O}_{3}$ aerogel and $\mathrm{RF} / \mathrm{Al}_{2} \mathrm{O}_{3}$ aerogel composites. As shown in Fig. 6, all the characteristic peaks of the $\mathrm{RF} / \mathrm{Al}_{2} \mathrm{O}_{3}$ aerogel composites relatively draw close to each other. Moreover, the characteristic peaks of $\mathrm{RF} / \mathrm{Al}_{2} \mathrm{O}_{3}$ aerogel composites are caused by the pure polymer (RF) and $\mathrm{Al}_{2} \mathrm{O}_{3}$ aerogels, and no obvious wavenumber shifts can be observed. The presence of water molecules is evidenced by the bands at $3426 \mathrm{~cm}^{-1}$ and $1621 \mathrm{~cm}^{-1}$, and there are no significant changes of the intensity with the decrease of $\mathrm{RF} /$ Al molar ratios. The two weak bands at $2973 \mathrm{~cm}^{-1}$ and $2898 \mathrm{~cm}^{-1}$ are related to the $\mathrm{C}-\mathrm{H}$ stretching vibration of

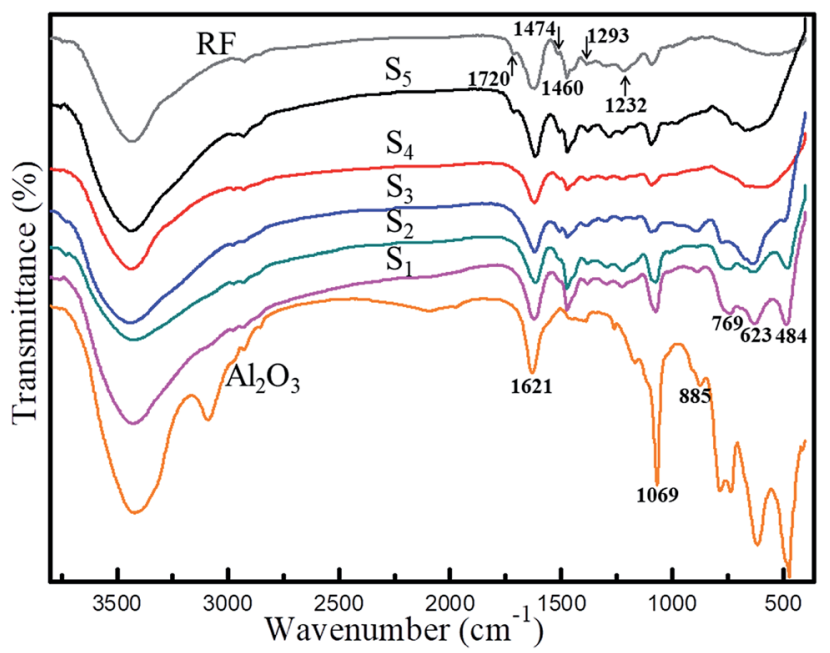

Fig. 6 FT-IR spectrum of $\mathrm{RF}, \mathrm{Al}_{2} \mathrm{O}_{3}$ aerogel and $\mathrm{RF} / \mathrm{Al}_{2} \mathrm{O}_{3}$ aerogels composites $\left(\mathrm{S}_{1}: \mathrm{RF} / \mathrm{Al}=0.5, \mathrm{~S}_{2}: \mathrm{RF} / \mathrm{Al}=0.67, \mathrm{~S}_{3}: \mathrm{RF} / \mathrm{Al}=1.0, \mathrm{~S}_{4}: \mathrm{RF} / \mathrm{Al}\right.$ $=1.5, \mathrm{~S}_{5}: \mathrm{RF} / \mathrm{Al}=2.0$ ).

hydrocarbon groups. The unique band only existed in $\mathrm{S}_{5}$ at $1720 \mathrm{~cm}^{-1}$ is associated with stretching of the $\mathrm{C}=\mathrm{O}$ bond of carbonyl or carboxyl groups. The bonds at $1460 \mathrm{~cm}^{-1}$ and $1474 \mathrm{~cm}^{-1}$ are due to the $-\mathrm{CH}_{2}-$ stretching vibration. The two bonds of $1293 \mathrm{~cm}^{-1}$ and $1232 \mathrm{~cm}^{-1}$ belong to the stretching vibration of $\mathrm{C}-\mathrm{O}-\mathrm{C}$ hydroxymethyl ether bond. It is well known that the lamellar structure of $\mathrm{AlOOH}$ has been previously reported by Yarbrough and Roy. ${ }^{53}$ The band at $1069 \mathrm{~cm}^{-1}$ is assigned to the $\mathrm{Al}-\mathrm{O}-\mathrm{H}$ stretching vibration of boehmite. The $\mathrm{OH}$ groups within the structure could form zigzag chains between the planes of oxygen ions, which could lead to the $\mathrm{OH}$ stretching modes due to their crystallographically inequivalent coupling effect. ${ }^{54}$ The bands at $885 \mathrm{~cm}^{-1}, 769 \mathrm{~cm}^{-1}, 623 \mathrm{~cm}^{-1}$ and $484 \mathrm{~cm}^{-1}$ are attributed to the Al-O structural vibration of boehmite. It is worth noting that the intensity of the bands corresponding to boehmite weakens gradually with the increase of RF/Al molar ratios, which is caused by the presence of polymer (RF) in its environment. Thus, the above FTIR analysis is consistent with the XRD and TGA results.

Fig. 7 shows the microstructures of the $\mathrm{RF} / \mathrm{Al}_{2} \mathrm{O}_{3}$ aerogel composites prepared with different $\mathrm{RF} / \mathrm{Al}$ molar ratios. All the samples exhibited porous structures of a typical colloidal gel, which is consisted of polymer ( $\mathrm{RF}), \mathrm{Al}_{2} \mathrm{O}_{3}$ nanoparticles and nanopores. It is found that with the increase of $\mathrm{RF} / \mathrm{Al}$ molar ratios, the morphology gradually changes from pearl-necklace networks to spherical particles. In addition, the as-prepared samples are comprised of interconnected spherical particles with diameters in the 5-15 nm range of polymer $(\mathrm{RF})$ and $\mathrm{Al}_{2} \mathrm{O}_{3}$ aerogel. Furthermore, the nanoparticles of the as-prepared samples progressively adjoin closely to each other and thus possesses the smallest nanopores with diameter at around 10$20 \mathrm{~nm}$ for the sample with $\mathrm{RF} / \mathrm{Al}=2$, when compared with the other samples. There are some large pores in the samples with $\mathrm{RF} / \mathrm{Al}=0.5,0.67\left(\mathrm{~S}_{1}, \mathrm{~S}_{2}\right)$, and some agglomeration particles appear in the samples with $\mathrm{RF} / \mathrm{Al}=1.5,2.0\left(\mathrm{~S}_{4}, \mathrm{~S}_{5}\right)$, which is not beneficial for large specific surface areas. In contrast, the 

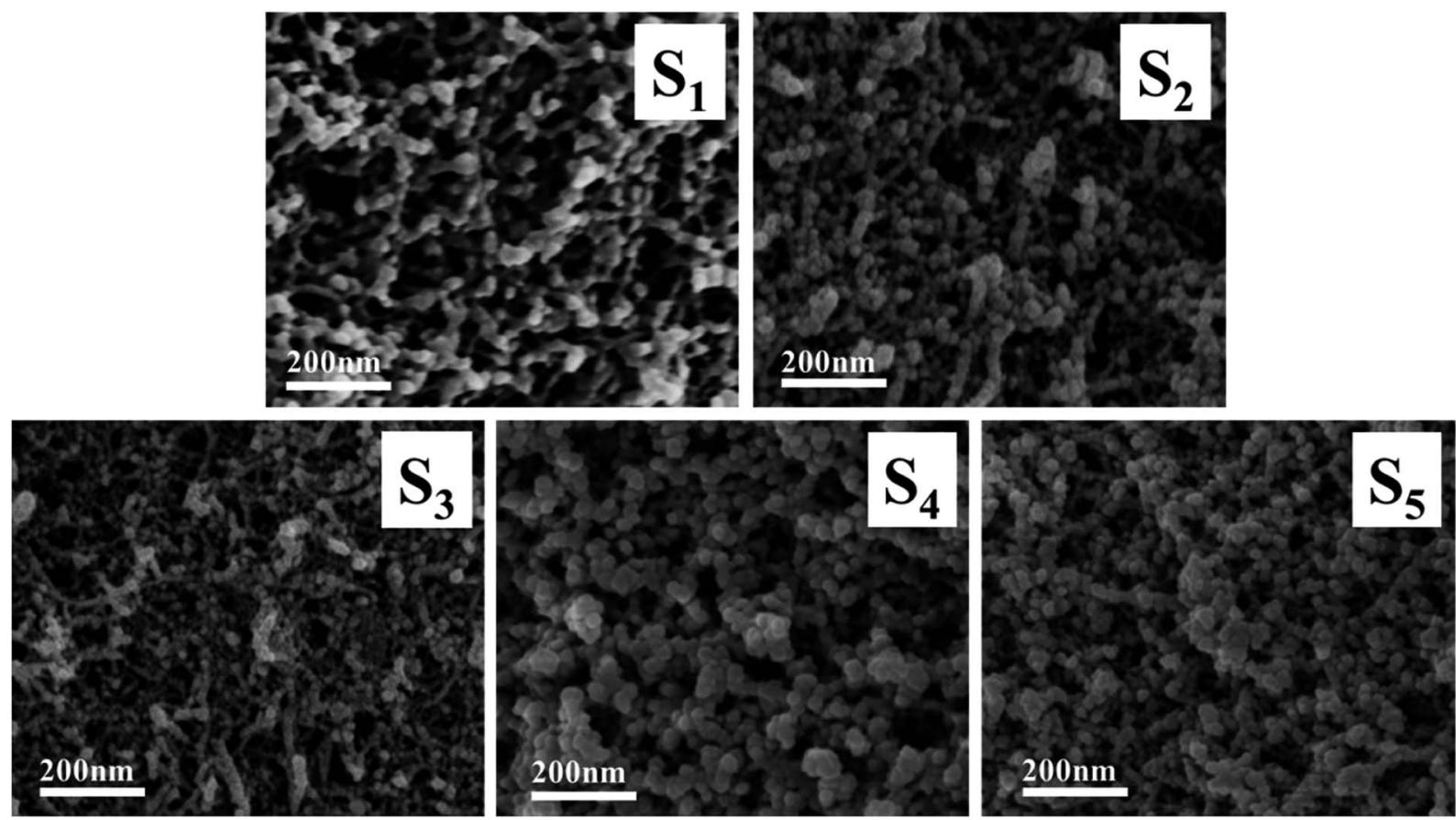

Fig. $7 \mathrm{SEM}$ images of $\mathrm{RF} / \mathrm{Al}_{2} \mathrm{O}_{3}$ aerogels composites prepared with different $\mathrm{RF} / \mathrm{Al}$ molar ratios $\left(\mathrm{S}_{1}: \mathrm{RF} / \mathrm{Al}=0.5, \mathrm{~S}_{2}: \mathrm{RF} / \mathrm{Al}=0.67, \mathrm{~S}_{3}: \mathrm{RF} / \mathrm{Al}=1.0\right.$, $\mathrm{S}_{4}: \mathrm{RF} / \mathrm{Al}=1.5, \mathrm{~S}_{5}: \mathrm{RF} / \mathrm{Al}=2.0$ ).

sample with $\mathrm{RF} / \mathrm{Al}=1\left(\mathrm{~S}_{3}\right)$ exhibits a significant homogeneous pore structures with diameters in the range of approximately 30-40 nm.

Transmission electron microscopy (TEM) was employed to further investigate the microstructure of the selected $\mathrm{RF} / \mathrm{Al}_{2} \mathrm{O}_{3}$ composite (Fig. 8, molar ratio $\mathrm{RF} / \mathrm{Al}=1$ ). The TEM image shows that alumina aerogels exhibit randomly interconnected networks made up of nanometer-sized fibrous alumina (dark field), which is similar to leaflets or sheets (2-5 nm wide, varying lengths), and RF aerogels consisted of interconnected amorphous spheroidal particles surrounding the fibrous alumina aerogels. Due to the fibrous alumina existed in $\mathrm{RF} / \mathrm{Al}_{2} \mathrm{O}_{3}$ aerogel

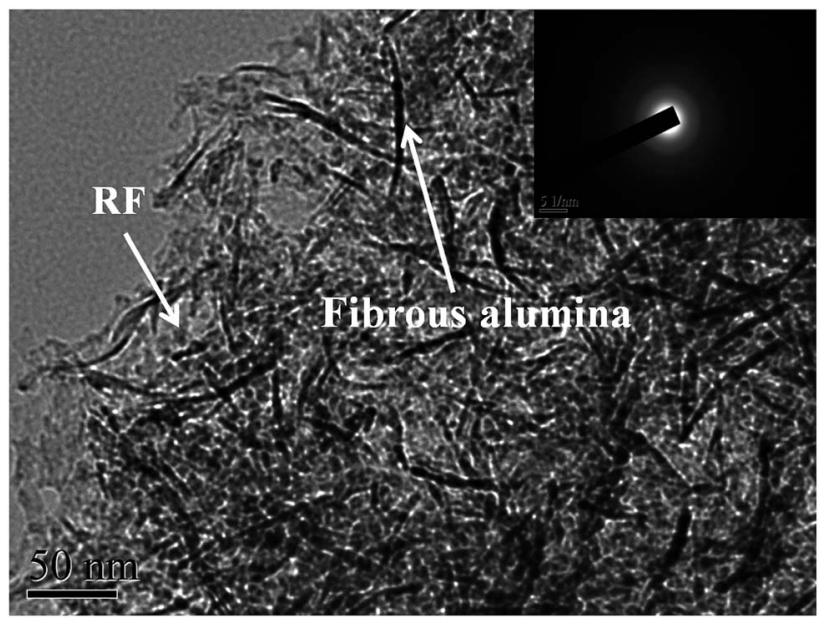

Fig. 8 TEM image of $\mathrm{RF} / \mathrm{Al}_{2} \mathrm{O}_{3}$ composite and SAED pattern (molar ratio $\mathrm{RF} / \mathrm{Al}=1$ ). composites, the mechanical properties of $\mathrm{RF} / \mathrm{Al}_{2} \mathrm{O}_{3}$ aerogel composites are further improved. The mechanism could be explained by the similar phenomena occurred in fiberreinforced system. Intriguingly, unlikely to the other aerogel composites reinforced by thick fibers, the nano-scaled fibrous alumina particles are beneficial to enhancing the mechanical performances of the as-prepared $\mathrm{RF} / \mathrm{Al}_{2} \mathrm{O}_{3}$ aerogel composites instead of destroying the internal pore structures.

The adsorption/desorption isotherms and pore size distribution curves of the samples are shown in Fig. 9. They are type IV curves with type $\mathrm{H} 1$ hysteresis loop in the IUPAC classification, which is characteristic of a mesoporous structure with cylindrical pores. The desorption cycles of the isotherms show a hysteresis loop for the five samples, which is generally attributed to the capillary condensation that occurs in the mesopores. It is found that with the increase of $\mathrm{RF} / \mathrm{Al}$ molar ratios, the ranges of the pore size distribution curves are changed from $0-100 \mathrm{~nm}$ to $0-30 \mathrm{~nm}$. As shown in Table 1 , the values of specific surface areas undergo the trend of first increase and then decrease with the increase of RF/Al molar ratios. Meanwhile, the average pore size of the samples gradually become smaller from $48.47 \mathrm{~nm}$ to $17.29 \mathrm{~nm}$. This is because the fact that with the increase of $\mathrm{RF} / \mathrm{Al}$ molar ratios, the pore structures of the $\mathrm{RF} / \mathrm{Al}_{2} \mathrm{O}_{3}$ aerogel composites become more homogenous and some macropore with diameters above $100 \mathrm{~nm}$ appear in the composites $\left(\mathrm{S}_{1}, \mathrm{~S}_{2}, \mathrm{~S}_{3}\right)$, which is favorable to increasing the specific surface areas of the composites. By contrast, the sample with $\mathrm{RF} / \mathrm{Al}=1$ shows the preferable framework structure with the highest specific surface areas of $722.75 \mathrm{~m}^{2} \mathrm{~g}^{-1}$ (as shown in Fig. 7 and Table 1). However, some agglomeration particles generate in the composites (Fig. 7) with 

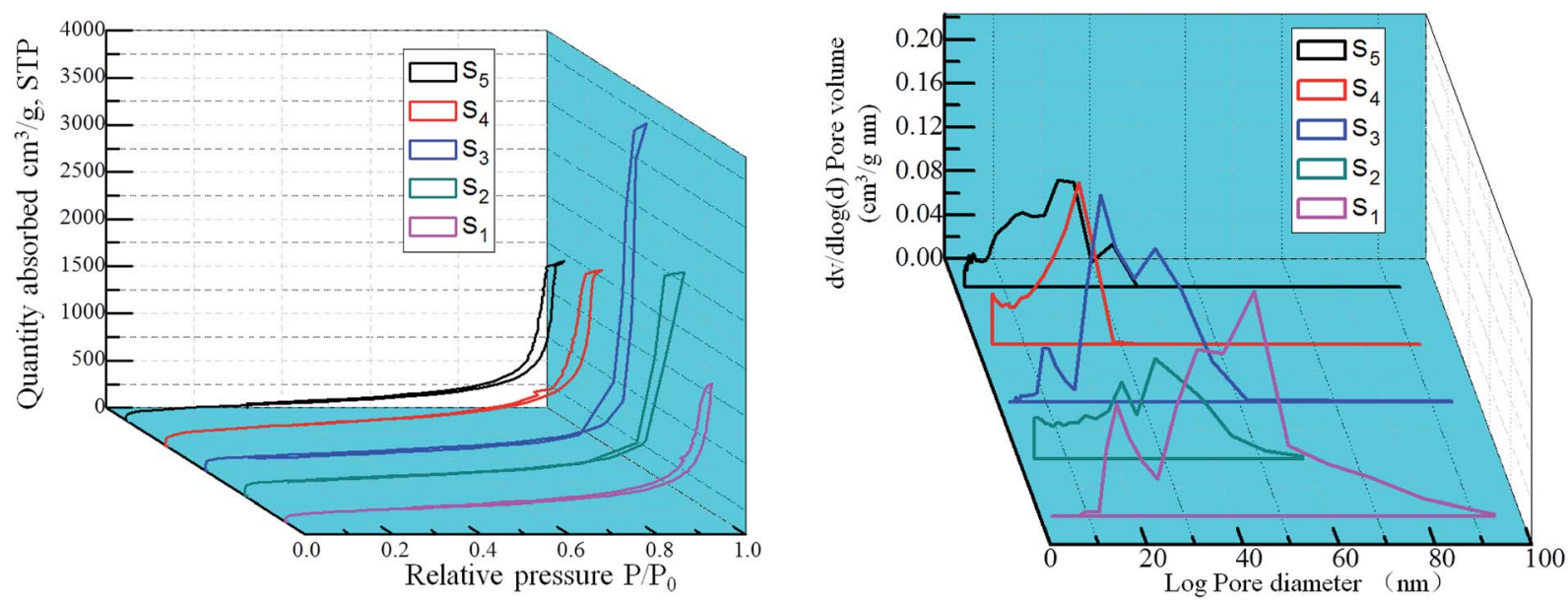

Fig. 9 Nitrogen adsorption/desorption isotherms and the pore size distribution curves of $\mathrm{RF} / \mathrm{Al}_{2} \mathrm{O}_{3}$ aerogels composites prepared with different $\mathrm{RF} / \mathrm{Al}$ molar ratios $\left(\mathrm{S}_{1}: \mathrm{RF} / \mathrm{Al}=0.5, \mathrm{~S}_{2}: \mathrm{RF} / \mathrm{Al}=0.67, \mathrm{~S}_{3}: \mathrm{RF} / \mathrm{Al}=1.0, \mathrm{~S}_{4}: \mathrm{RF} / \mathrm{Al}=1.5, \mathrm{~S}_{5}: \mathrm{RF} / \mathrm{Al}=2.0\right)$.

the continuous increase of $\mathrm{RF} / \mathrm{Al}$ molar ratio, resulting in the decrease of specific surface area.

\section{Conclusions}

Monolithic $\mathrm{RF} / \mathrm{Al}_{2} \mathrm{O}_{3}$ aerogel composites with mutually interpenetrating organic/inorganic network structure were successfully synthesized by a sol-gel method combined with $\mathrm{CO}_{2}$ supercritical fluid drying technique. The formation mechanism and the effects of $\mathrm{RF} / \mathrm{Al}$ molar ratios on structure evolution and physicochemical properties of the $\mathrm{RF} / \mathrm{Al}_{2} \mathrm{O}_{3}$ aerogel composites were systematically discussed. The as-prepared samples show uniform mesoporous structures with low bulk density, low thermal conductivity, high specific surface area and excellent mechanical performance, without the use of structural reinforcement materials. Particularly, the sample with molar ratio $\mathrm{RF} / \mathrm{Al}=1$ shows the highest compressive strength and Young's modulus, primarily due to the homogeneous interpenetrating network structure and fibrous alumina reinforcement. Therefore, this novel porous interpenetrating organic/inorganic framework material, consisting of aerogels with outstanding mechanical behavior, offers a broad scope of application in fields requiring the use of aerogel materials.

\section{Conflicts of interest}

The authors declare that there are no conflicts of interest.

\section{Acknowledgements}

The authors acknowledge the supports from the National Natural Science Foundation of China (51702156 and 51602151), the Priority Academic Program Development of Jiangsu Higher Education Institution (PAPD)—China, the Natural Science Foundation of Jiangsu Province-China (BK20161002 and BK20161003), the project of Jiangsu provincial Six Talent Peaks (XCL-231) and Jiangsu Collaborative Innovation Center for Advanced Inorganic Function Composites.

\section{References}

1 L. Huber, S. Y. Zhao, W. J. Malfait and M. M. Koebel, Angew. Chem., Int. Ed., 2017, 56, 1-5.

2 N. Leventis, S. Mulik, X. Wang, A. Dass, V. U. Patil, C. Sotiriou-Leventis, H. Lu, G. Churu and A. Capecelatro, J. Non-Cryst. Solids, 2008, 354, 632-644.

3 T. F. Baumann, A. E. Gash, G. A. Fox, J. H. Satcher Jr, and L. W. Hrubesh, in Handbook of Porous Solids, ed. F. Schuth, K. S. W. Sing and J. Weitkamp, 2002.

4 S. Cui, W. W. Cheng, X. D. Shen, M. Fan, A. T. Russell, Z. W. Wu and X. B. Yi, Energy Environ. Sci., 2011, 4, 20702074.

5 S. Islama, H. Bakhtiara, W. Shukria, M. Aziza, S. Riazb and S. Naseemb, Microporous Mesoporous Mater., 2019, 274, 183-189.

6 M. Alnaief, S. Antonyuk, C. M. Hentzschel, C. S. Leopold, S. Heinrich and I. Smirnova, Microporous Mesoporous Mater., 2012, 160, 167-173.

7 X. D. Wu, G. F. Shao, X. D. Shen, S. Cui and L. Wang, RSC Adv., 2016, 6, 5611-5620.

8 Y. Zhong, Y. Kong, X. D. Shena, S. Cui, X. B. Yi and J. J. Zhang, Microporous Mesoporous Mater., 2013, 172, 182-189.

9 Y. Zhao, Y. Li and R. B. Zhang, Ceram. Int., 2018, 44, 2126221268.

10 H. M. Cheng, H. F. Xue, C. Q. Hong and X. H. Zhang, RSC Adv., 2016, 6, 75793-75804.

11 J. P. Randall, M. A. B. Meador and S. C. Jana, ACS Appl. Mater. Interfaces, 2011, 3, 613-626.

12 S.-H. Carolina, A. Romero, J. L. Valverde and S.-S. Luz, J. Mater. Sci., 2018, 53, 1556-1567.

13 J. F. Yang, Q. H. Wang, T. M. Wang and Y. M. Liang, RSC Adv., 2016, 6, 26271-26279.

14 X. B. Hou, R. B. Zhang and D. N. Fang, Ceram. Int., 2017, 43, 9547-9551.

15 L. M. Tong, J. Y. Lou, R. R. Gattass, S. L. He, X. W. Chen, L. Liu and E. Mazur, Nano Lett., 2005, 5, 259-262. 
16 C. C. Li, X. D. Cheng, Z. Li, Y. L. Pan, Y. J. Huang and L. L. Gong, J. Non-Cryst. Solids, 2017, 457, 52-59.

17 B. Yuan, S. Ding, D. Wang, G. Wang and H. Li, Mater. Lett., 2012, 75, 204-206.

18 J. He, X. L. Li, D. Su, H. M. Ji and X. J. Wang, J. Eur. Ceram. Soc., 2016, 36, 1487-1493.

19 R. B. Zhang, X. B. Hou, C. S. Ye and B. L. Wang, J. Alloys Compd., 2017, 699, 511-516.

20 X. G. Yang, Y. T. Sun and D. Q. Shi, J. Non-Cryst. Solids, 2012, 358, 519-524.

21 R. L. Liua, X. Dong, S. Y. Xiea, T. Jia, Y. J. Xue, J. C. Liu, W. Jing and A. R. Guo, Chem. Eng. J., 2019, 360, 464-472.

22 Z. J. Dong and L. I. Xuan-ke, New Chem. Mater., 2006, 34, 5861.

23 T. H. Hsieh and Y. S. Huang, J. Mater. Sci., 2017, 52, 35203534.

24 A. Ślosarczyk, S. Wojciech, Z. Piotr and J. Paulina, J. NonCryst. Solids, 2015, 416, 1-3.

25 Y. Zhong, J. J. Zhang, X. D. Wu, X. D. Shen, S. Cui and C. H. Lu, J. Sol-Gel Sci. Technol., 2017, 84, 129-134.

26 K. Koziol, J. Vilatela, A. Moisala, M. Motta, P. Cunniff, M. Sennett and A. Windle, Science, 2007, 318, 1892-1895.

27 S. J. Shin, S. O. Kucheyev, M. A. Worsley and A. V. Hamza, Carbon, 2012, 50, 5340-5350.

28 K. L. Stano, S. Faraji, O. Yildiz, H. Akyildiz, P. D. Bradford and J. S. Jur, RSC Adv., 2017, 7, 27923-27931.

29 F. C. Cao, L. L. Ren and X. A. Li, RSC Adv., 2015, 5, 1802518028.

30 M. Litschauer, M.-A. Neouze, E. Haimer, U. Henniges, A. Potthast, T. Rosenau and F. Liebner, Cellulose, 2011, 18, 143-149.

31 A. Demilecamps, C. Beauger, C. Hildenbrand and A. Rigacci, Polymer, 2015, 122, 293-300.

32 N. Leventis, C. Sotiriou-Leventis, G. Zhang and A.-M. M. Rawashdeh, Nano Lett., 2002, 2, 957-960.

33 A. Karout, P. Buisson, A. Perrard and A. Pierre, J. Sol-Gel Sci. Technol., 2005, 36, 163-171.

34 L. F. Hu, C. A. Wang and Y. Huang, J. Mater. Sci., 2010, 45, 3242-3246.
35 V. Drach, M. Wiener, G. Reichenauer, H. P. Ebert and J. Fricke, Int. J. Thermophys., 2007, 28, 1542-1562.

36 Z. Li, X. D. Cheng, S. He, X. J. Shi, L. L. Gong and H. P. Zhang, Composites, Part A, 2016, 84, 316-325.

37 F. Rinbot and C. Sanchez, New J. Chem., 1994, 18, 1007-1048.

38 N. Leventis, C. Sotiriou-Leventis, G. H. Zhang and A.-M. M. Rawashdeh, Nano Lett., 2002, 2, 957-960.

39 N. Nazeran and J. Moghaddas, J. Non-Cryst. Solids, 2017, 461, 1-11.

40 H. Hu, Z. B. Zhao, W. B. Wan, Y. Gogotsi and J. S. Qiu, ACS Appl. Mater. Interfaces, 2014, 6, 3242-3249.

41 Y. Özbakır, Z. Ulker and C. Erkey, J. Supercrit. Fluids, 2015, 105, 108-118.

42 Z. Li, L. L. Gong, C. C. Li, Y. L. Pan, Y. J. Huang and X. D. Cheng, J. Non-Cryst. Solids, 2016, 454, 1-7.

43 H. Maleki, L. Durães and A. Portugal, Microporous Mesoporous Mater., 2014, 197, 116-129.

44 M. Schwan, R. Tannert and L. Ratke, J. Supercrit. Fluids, 2016, 107, 201-208.

45 Y. Zhong, Y. Kong, J. J. Zhang, X. D. Shen and S. Cui, J. Porous Mater., 2014, 21, 653-658.

46 A. H. Alaoui, T. Woignier, G. W. Scherer and J. Phalippou, J. Non-Cryst. Solids, 2008, 354, 4556-4561.

47 G. Q. Zu, J. Shen, X. Q. Wei, X. Y. Ni, Z. H. Zhang, J. C. Wang and G. G. Liu, J. Non-Cryst. Solids, 2011, 357, 2903-2906.

48 M. A. Worsley, S. O. Kucheyev, J. D. Kuntz, T. Y. Olson, T. Y. J. Han, A. V. Hamza, J. H. Satcher Jr and T. F. Baumann, Chem. Mater., 2011, 23, 3054-3061.

49 M. M. Girona, E. Martinez, A. Roig, J. Esteve and E. Molins, J. Non-Cryst. Solids, 2001, 285, 244-250.

50 K. A. D. Obrey, K. V. Wilson and D. A. Loy, J. Non-Cryst. Solids, 2011, 357, 3435-3441.

51 S. Mulik, C. Sotiriou-Leventis and N. Leventis, Chem. Mater., 2008, 20, 6985-6997.

52 N. Leventis, N. Chandrasekaran, A. G. Sadekar, C. SotiriouLeventis and H. B. Lu, J. Am. Chem. Soc., 2009, 131, 45764577.

53 W. A. Yarbrough and R. Roy, J. Mater. Res., 1987, 2, 494-515. 54 H. W. Hou, Y. Xie, Q. Yang, Q. X. Guo and C. R. Tan, Nanotechnology, 2005, 16, 741-745. 